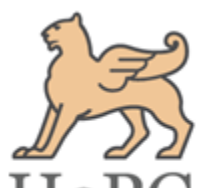

$\mathrm{HePG}$

ISSN: 2348-1900

Plant Science Today

http://horizonepublishing.com/journals/index.php/PST

Research Article

\title{
Checklist of Mosses (Bryophyta) of Bodamalai Hills in Eastern Ghats, Tamil Nadu
}

\author{
R. Palani, S. Sahaya Sathish*, T. Thamizharasi, and P. Vijayakanth \\ Centre for Cryptogamic Studies, Department of Botany, St. Joseph’s College (Autonomous), Tiruchirappalli, Tamil Nadu 620002, India
}

Article history

Received: 18 October 2016

Accepted: 30 November 2016

Published: 03 January 2017

(C) Palani et al. (2017)

\section{Editor}

K. K. Sabu

\section{Publisher}

Horizon e-Publishing Group

Corresponding Author

S. Sahaya Sathish

$\square_{\text {sahayasathish@yahoo.in }}$

\begin{abstract}
Bodamalai Hills, situated on the Southern Eastern Ghats of Tamil Nadu, were explored for mosses (bryophyta) for the first time. As a result a checklist of mosses has been prepared comprising 52 species belonging to 38 genera and 21 families. The dominant families with the maximum number of species are Pottiaceae, Bryaceae, Stereophyllaceae, Sematophyllaceae and Brachytheciaceae. The dominant genera are Brachymenium and Bryum and the dominant species are Barbula javanica and Bryum capillare.
\end{abstract}

Keywords

Bodamalai Hills; Eastern Ghats; mosses; Tamil Nadu

Palani, R., S. S. Sathish, T. Thamizharasi, and P. Vijayakanth. 2017. Checklist of Mosses (Bryophyta) of Bodamalai Hills in Eastern Ghats, Tamil Nadu. Plant Science Today 4(1): 49-54. http://dx.doi.org/10.14719/pst.2017.4.1.278

\section{Introduction}

Bryophytes were the pioneers to colonize a terrestrial habitat from an aquatic one. They are the second largest group of terrestrial plants next to angiosperms (Chopra, 1975). They represent a heterogeneous assemblage of plants which include liverworts (Marchantiophyta), hornworts (Anthocerophyta) and mosses (Bryophyta) that impart lush greenery, a verdant cover, spongy bed or carpet in every possible habitat. They colonize on rocks, road-side cuts, walls and old monument remains, as epiphytes on trees, logs, stumps, leaves and forest floors. The Indian sub-continent is bestowed with a wide range of phytogeographical regions with varied ecological conditions. Currently about 2,489 taxa of bryophytes have been reported from India (Dandotiya et al., 2011). In recent years floristic studies on the bryophytes of the Eastern Ghats have been made by (Kumar and
Krishnamurthy, 2007; Sahaya Sathish, 2013; Rani et al., 2014; Sathish et al., 2014; Biju and Daniels, 2016 and Mishra et al., 2016). Studies on the ecology and distribution of bryophytes along the north coastal zone of the Andhra Pradesh in the Eastern Ghats have been made by (Murty et al., 2011, Rao and Rao, 2013, and Dash et al., 2009).

\section{Study Area}

Bodamalai hills are situated in the Southern Eastern Ghats and fall under Rasipuram Taluk in Namakkal District, Tamil Nadu. Rasipuram is the nearest town to Bodamalai hills and Thengalpalayam, Vadugam and Kullampatti are the neighbouring villages. The hills lie between $11^{\circ}$ $14 " 46^{\prime}-12^{\circ} 53^{\prime \prime} 30^{\prime}$ North latitude and $77^{\circ} 32^{\prime \prime} 52^{\prime}-78^{\circ}$ 53"05' East longitude. The maximum elevation of the hills is ca 1, $200 \mathrm{~m}$ (Sathiyaraj \& al., 2015; Fig. 1. $\mathrm{a}, \mathrm{b})$. 

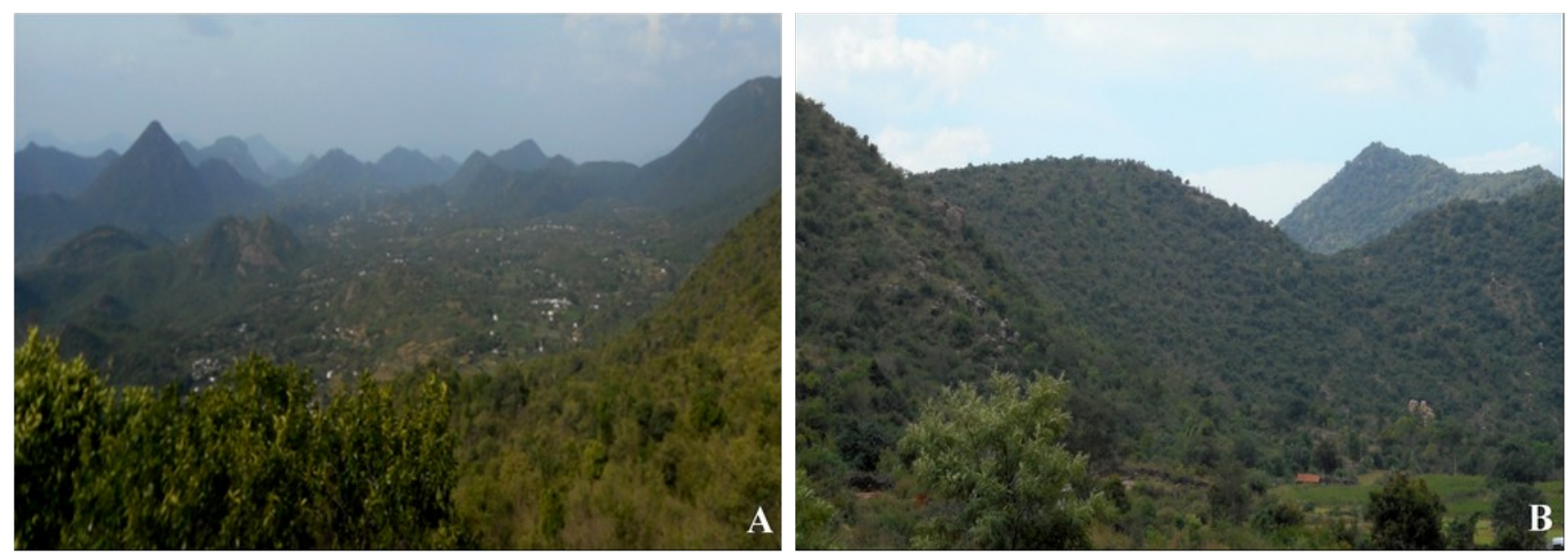

Figure 1 (A, B) Views of Bodamalai Hills

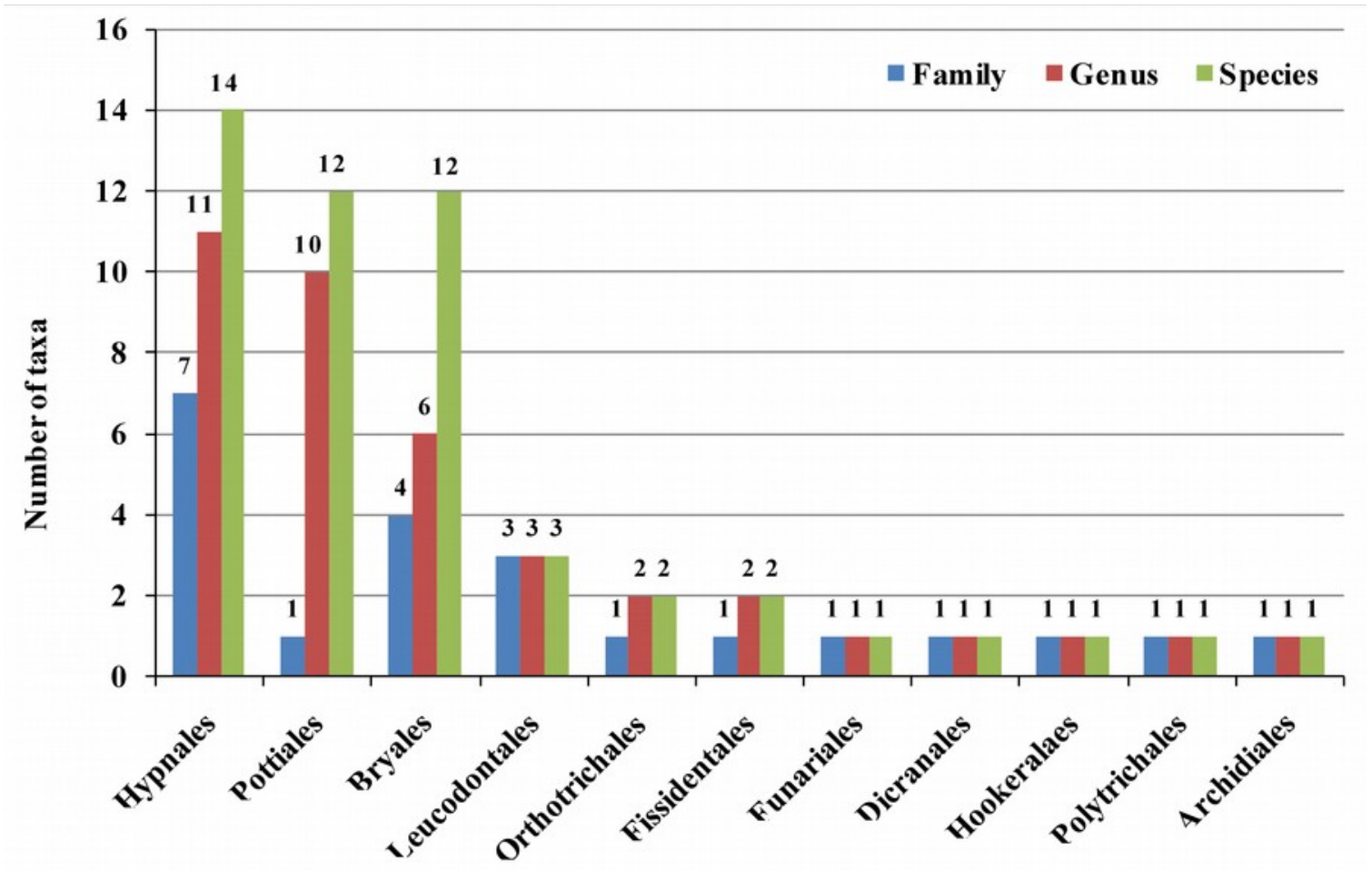

Different order of Mosses in Bodamalai Hills

Figure 2. Representation of different orders of mosses of Bodamalai hills

\section{Materials and Methods}

Collections were made following traditional methods. Surveys were carried out from August 2013 to March 2016 immediately after monsoon rains. Simple methodology was adopted to collect specimens in the field. A knife was used to peel off specimens from tree barks, rocks and other substrata. Specimens were dried at room temperature on blotting paper and placed carefully in brown paper envelopes of dimension $15 \times 10 \mathrm{~cm}$. Collection details were noted including locality, date of collection, habitat type, altitude etc. Identifications were made with the help of Gangulee's 'Mosses of Eastern India and Adjacent
Regions' (1969-1980), Manju et al., Bryophytes of Wayanad in Western Ghats (2005) and other related works and also by comparing with protologues. All moss taxa included in the list were checked against the database (www.tropicos.org and www.theplantlist.org) and Daniels (2010) concerning current acceptable nomenclature.

\section{Results and Discussion}

The present study on the mosses of Bodamalai hills reveals the occurrence of a total number of 52 species belonging to 38 genera and 21 families, (Table 1). The most diverse order is Hypnales with 


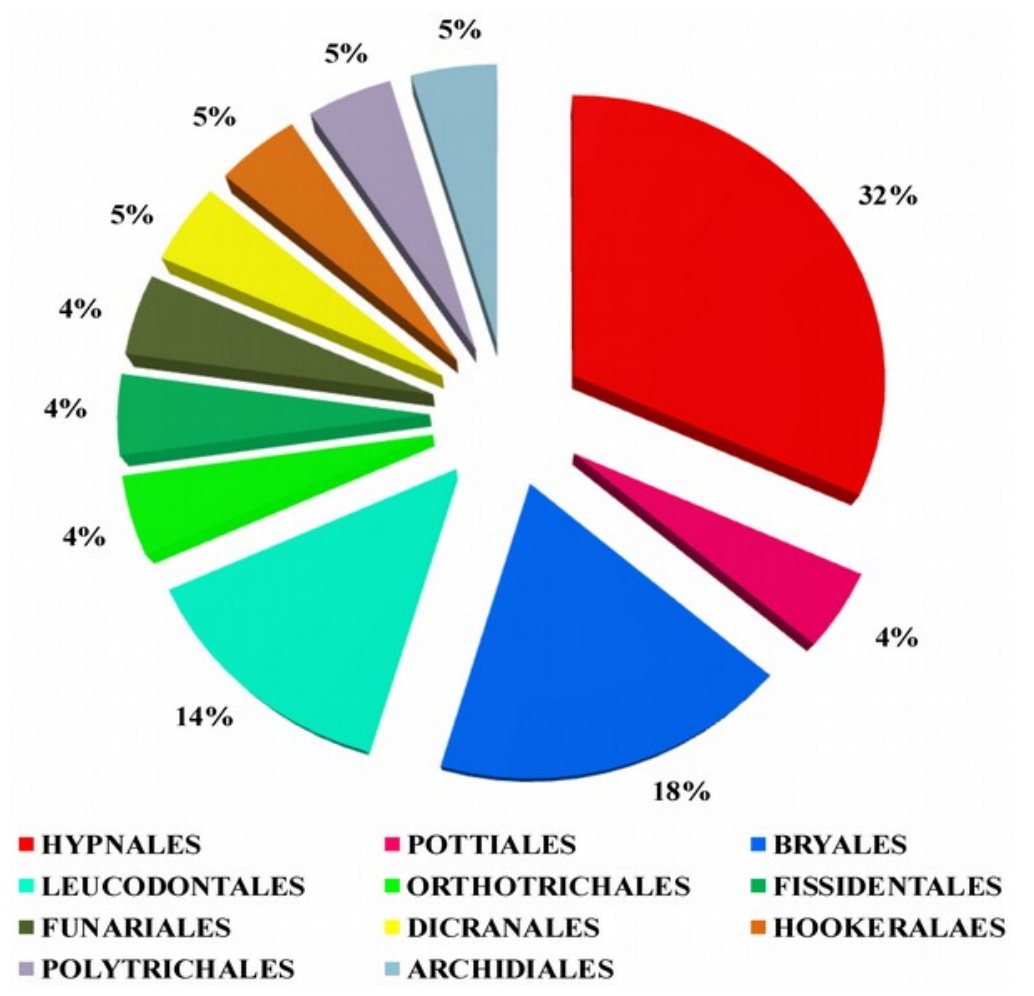

Figure 3. Percentage Distribution of different orders of Mosses of Bodamalai hills

14 species, 11 genera and 7 families followed by Pottiales with 12 species belonging to 10 genera and 1 families and Bryales with 12 species, 6 genera and 4 families. The most predominant family is Pottiaceae comprising 10 genera and 12 species followed by Bryaceae with 3 genera and 10 species (Fig. 2 - 3). Most of the species are rupicolous and a few are lignicolous and only on species folicolous. The evergreen forests in the study area harbour a maximum of 33 species. On the contrary, plantations harbour only 5 species. This observation highlights the need for conservation of the relict, fragmented evergreen forests.

\section{Competing Interest}

The authors declare that they have no competing interests.

\section{Authors' contributions}

All authors read and approved the final manuscript.

\section{Acknowledgements}

The authors are thankful to the University Grants Commission (UGC), New Delhi - for financial support (F. No. 41 - 449/2012(SR) Dt.07/07/2012). We also thank Dr. Manju, C.N., Assistant Professor, Department of Botany, Zamorin's Guruvayurappan College, Kozhikode, Kerala for the kind help in identification.

\section{References}

Biju, P. M. and A. E. D. Daniels. 2016. Two species of Isopterygium Mitt. New to the Eastern Ghats in Peninsular India. Plant Science Today 3(2): 129-134. doi: 10.14719/pst.2016.3.2.223

Chopra, R. S. 1975. Taxonomy of Indian Mosses CSIR, Botanical Monograph No. 10, CSIR Publication, New Delhi.

Dandotiya, D., H. Govandapayari, S. Suman and P. L. Uniyal. 2011. Checklist of the bryophytes of India. Archive for Bryology: 88.

Daniels, A. E. D. 2010. Checklist of the bryophytes of Tamil Nadu, India. Archive for Bryology 65: $117 \mathrm{pp}$. ISSN 0945-3466.

Dash, P. K., S. Sahu, and D. K. Saxena. 2009. Bryoflora of Baphlamali Hills in Eastern Ghats of Orissa, India, EPTRI - ENVIS Newsletter. 15(1):1- 8.

Gangulee, H. C. 1969-1980. Mosses of Eastern India \& Adjacent regions, Vol. I-III. Fascicles1- 8), Calcutta.

Kumar, G., V. and K. V. Krishnamurthy. 2007. Moss flora of Shervaroy Hills of Eastern Ghats (South India). In: Nath, V. \& A. K. Asthana (eds.), Current Trends in Bryology, 227-243. Bishen Singh, Mahendra Pal Singh, Dehra Dun.

Manju, C. N., K. P. Rajesh and P. V. Madhusoodanan. 2005. Bryophytes of Wayanad in Western Ghats, Malabar. Natural History Society, Kerala.

Mishra, M., P. K. Dash, A. Alam, S. Sahoo and R. Das. 2016. Current status of diversity and distribution of Bryophytes of odisha. Plant Science Today 3(2): 186194. doi: 10.14719/pst.2016.3.2.222

Narasimha Rao G., M. and K. Srinivasa Rao. 2013. Distribution, density and economic importance of Bryophytes of G.Madugula forest division, Eastern Ghats of India. International Research Journal of Pharmaceutical and Applied Sciences 3 (4): 27-28. 
Table 1. List of mosses occurring in Bodamalai hills

Name of the species

Anoectangium Schwägr.

1. Anoectangium thomsonii Mitt.

Syn.: Anoectangium bicolor Renauld \& Cardot

\section{Archidium Brid.}

2. Archidium birmannicum Mitt. ex Dixon

Barbula Hedw.

3. Barbula indica (Hook.) Spreng.

4. Barbula javanica Dozy \& Molk.

Syn.: Hydrogonium consanguineum (Thwaites et Mitt.) Hilp.

\section{Brachymenium Schwägr}

5. Brachymenium leptophyllum Bruch \& Schimp. ex Mull.Hal.) Bruch \& Schimp.Bryaceae ex A. Jaeger

6. Brachymenium sikkimense Renauld \& Cardot

7. Brachymenium acuminatum Harv.

8. I. BRACHYMENIUM BRYOIDES HOOK. EX SCHWÄGR.

9. $\quad$ Brachymenium exile Dozy \& Molk.) Bosch \& Sande Lac. Bryum Hedw

10. Bryum cellulare Hook.

11. Bryum capillare Hedw.

12. Bryum caespiticium Hedw.

13. Bryum argenteum Hedw. Campylopus Brid.

14. Campylopus subluteus (Mitt.) A. Jaeger Didymodon Hedw.

15. Didymodon ovatus (Mitt.) A. Jaeger

16. Didymodon asperifolius (Mitt.) H.A. Crum, Steere \& L.E. Anderson

Entodon Müll. Hal.

17. Entodon rubicundus (Mitt.) A. Jaeger Entodontopsis Broth.

18. Entodontopsis tavoyensis (Hook. ex Harv.) W.R. Buck \& Ireland Fabronia Raddi

19. Fabronia schensiana Müll.Hal.

Bryaceae

Bryales

Pottiaceae

Pottiaceae Pottiales

Archidiales

Pottiales Pottiales 
Table 1 (Contd). List of mosses occurring in Bodamalai hills

\begin{tabular}{|c|c|c|c|}
\hline & Name of the species & Family & Order \\
\hline \multicolumn{4}{|c|}{ Macromitrium Brid. } \\
\hline \multirow[t]{2}{*}{28.} & Macromitrium sulcatum (Hook.) Brid. & Orthotrichaceae & Orthotrichales \\
\hline & Philonotis Brid. & & \\
\hline \multirow{2}{*}{29.} & Philonotis hastata (Duby) Wijk \& Margad. & Bartramiaceae & Bryales \\
\hline & Pinnatella M. Fleisch. & & \\
\hline \multirow[t]{2}{*}{30.} & Pinnatella foreauana Thér. \& P. de la Varde & Neckeraceae & Leucodontales \\
\hline & Platyhypnidium M. Fleisch. & & \\
\hline \multirow[t]{2}{*}{31.} & Platyhypnidium muelleri (A. Jaeger) M. Fleisch. & Brachytheciaceae & Hypnales \\
\hline & Pogonatum P. Beauv. & & \\
\hline \multirow[t]{2}{*}{32.} & Pogonatum neesii (Müll.Hal.) Mitt. & Polytrichaceae & Polytrichales \\
\hline & Pohlia Hedw. & & \\
\hline \multirow[t]{2}{*}{33.} & Pohlia ludwigii (Spreng. ex Schwägr.) Broth. & Bryaceae & Bryales \\
\hline & Pseudotaxiphyllum Z. Iwats. & & \\
\hline \multirow[t]{2}{*}{34.} & Pseudotaxiphyllum elegans (Brid.) Z. Iwats. & Hypnaceae & Hypnales \\
\hline & Pseudoleskea Bruch \& Schimp. & & \\
\hline \multirow[t]{2}{*}{35.} & Pseudoleskea incurvata (Hedw.) Loeske & Leskeaceae & Hypnales \\
\hline & Pterobryopsis M. Fleisch. & & \\
\hline \multirow[t]{2}{*}{36.} & Pterobryopsis orientalis (Müll.Hal.) M. Fleisch. & Pterobryaceae & Leucodontales \\
\hline & Pyrrhobryum Mitt. & & \\
\hline \multirow[t]{2}{*}{37.} & Pyrrhobryum spiniforme (L. ex Hedw.) Mitt. & Rhizogoniaceae & Bryales \\
\hline & Racopilum P. Beauv. & & \\
\hline \multirow[t]{2}{*}{38.} & $\begin{array}{l}\text { Racopilum orthocarpum Wilson ex Mitt. } \\
\text { Syn.: Racopilum siamense Dixon }\end{array}$ & Racopilaceae & Bryales \\
\hline & Rhynchostegiella (Schimp.) Limpr. & & \\
\hline 39. & Rhynchostegiella divaricatifolia (Renauld \& Cardot) Broth. & Brachytheciaceae & Hypnales \\
\hline \multirow[t]{2}{*}{40.} & Rhynchostegiella ramicola (Broth.) Broth. & Brachytheciaceae & Hypnales \\
\hline & Schlotheimia Brid. & & \\
\hline \multirow[t]{2}{*}{41.} & Schlotheimia grevilleana Mitt. & Orthotrichaceae & Orthotrichales \\
\hline & Semibarbula Herzog ex Hilp. & & \\
\hline \multirow[t]{2}{*}{42.} & Semibarbula ranuii Gangulee. & Pottiaceae & Pottiales \\
\hline & Sematophyllum Mitt. & & \\
\hline \multirow[t]{2}{*}{43.} & Sematophyllum humile (Mitt.) Broth. & Sematophyllaceae & Hypnales \\
\hline & Splachnobryum Müll. Hal. & & \\
\hline \multirow[t]{2}{*}{44.} & Splachnobryum assamicum Dixon & Splachnobryaceae & Funariales \\
\hline & Stereophyllum Mitt. & & \\
\hline 45. & Stereophyllum radiculosum (Hook.) Mitt. & Stereophyllaceae & Hypnales \\
\hline \multirow[t]{2}{*}{46.} & Stereophyllum fulvum (Harv.) A. Jaeger & Stereophyllaceae & Hypnales \\
\hline & Taxiphyllum M. Fleisch. & & \\
\hline \multirow[t]{2}{*}{47.} & Taxiphyllum taxirameum (Mitt.) M. Fleisch. & Hypnaceae & Hypnales \\
\hline & Tortella (Lindb.) Limpr & & \\
\hline \multirow[t]{2}{*}{48.} & Tortella tortuosa (Schrad. ex Hedw.) Limpr. & Pottiaceae & Pottiales \\
\hline & Trichostomum Hedw. & & \\
\hline \multirow[t]{2}{*}{49.} & Trichostomum subminusculum Dixon \& P. de la Varde & Pottiaceae & Pottiales \\
\hline & Trachyphyllum A. Gepp & & \\
\hline \multirow[t]{2}{*}{50} & Trachyphyllum inflexum (Harv.) A. Gepp & Entodontaceae & Hypnales \\
\hline & Wijkia H.A. Crum & & \\
\hline 51. & Wijkia surcularis (Mitt.) H.A. Crum & Sematophyllaceae & Hypnales \\
\hline 52. & Wijkia deflexifolia (Mitt. ex Renauld \&Cardot) H.A. Crum & Sematophyllaceae & Hypnales \\
\hline
\end{tabular}


Pragaya Murty, P. D., Srinivasa Rao and G. Narasimha Rao. 2011. Distribution and species composition of Bryophytic flora of Punyagiri Hill, Vizianagaram district, Andhra Pradesh, India, Advances in Pollen Spore Res. 30: 73-77.

Sahaya Sathish, S. 2013. Moss diversity in the Kolli hills of the Eastern Ghats of Tamil Nadu, Journal of Basic and applied biology, Special issue pp. 322 - 334.

Sahaya Sathish, S., T. Thamizharasi, R. Palani, P. Vijayakanth, and A. Vimala. 2014. Checklist of mosses (Bryopsida) of the Kalrayan Hills in the Eastern Ghats of Tamil Nadu, India. International Journal of Research in Engineering and Bioscience 2: 28 - 33.
Sandhya Rani, S., M. Sowghandhika, K. S. Nagesh, B. Susheela and T. Pullaiah. 2014. Bryophytes of Andhra Pradesh. Bishen Singh, Mahendra Pal Singh, Dehradun, India. pp. 275.

Sathiyaraj, R., Sarvalingam A. A. Arulbalachandran and R. K. Reddy. 2015. Diversity of Ethnomedicinal Plants in Bodamalai Hills, Eastern Ghats, Namakkal District, Tamil Nadu. Journal of Plant Sciences 3: 77 - 84. doi: 10.11648/j.jps.20150302.16

TROPICOS database (www.tropicos.org and www.theplantlist.org) 2016. 